\title{
Therapeutic Implication of Botulinum Toxin B for Treatment of Muscle Hypertrophy from In Vivo Study
}

\author{
Teo Jeon Shin, M.D., Kwang-Suk Seo, M.D, Ph.D., and Hyun Jeong Kim, M.D, Ph.D. \\ Department of Dental Anesthesiology and Dental Research Institute, Seoul National University School of Dentistry
}

\author{
Abstract \\ 근육비대의 치료에 있어 보툴리눔 독소 $\mathbf{B}$ 형의 유용성 \\ 서울대학교 치의학대학원 치과마취과학교실 \\ 신터전 · 서광석 · 김현정
}

배경: 보툴리눔 독소 A형은 강직성 질환을 비롯한 여러 질환의 치료제로 널리 사용되고 있다. 최근에 보툴리눔 독소 $\mathrm{A}$ 형은 근육비대를 치료하기 위해 널리 이용되고 있다. 하지만 보툴리눔 독소의 근육비대의 치료효과에 대해서 알려진 바가 거의 없다. 본 연구는 토끼 정강뼈 근육에 보툴 리눔 $\mathrm{A}, \mathrm{B}$ 형을 주입 후 시간경과에 따른 근육의 위축을 확인하여 근육비대의 치료에 보툴리눔 $\mathrm{B}$ 형이 효과적인지 확인하고자 하였다.

방법: 36마리의 토끼를 4그룹으로 분류하였다(1 그룹: 생리식염수 주사: 2 그룹: 보툴리눔 독소 $\mathrm{A}, \mathrm{B}-2 \mathrm{U}, 3$ 그룹: 보툴리눔 독소 A, B - 5U, 4 그룹: 보툴리눔 독소 A, B - 10U). 정강뼈근육에 보툴리눔 독소 $\mathrm{A}, \mathrm{B}$ 형을 주입 후 $1,2,4$ 주에 정강뼈 근육의 부피를 측정하였다. 신경자극기를 이용 하여 독소 주입 후 $1,2,4$ 주의 근육의 단일 수축을 확인하여 근육기능의 변화여부를 확인하였다.

결과: 보툴리눔 독소 B형을 주입시 통계적으로 유의하지 않지만 $\mathrm{A}$ 형에 비해 근육 부피의 감소 가 관찰되었다 $(\mathrm{P}>0.05)$. 반면, 근육의 단일 수축은 보툴리눔의 용량에 관계없이 $\mathrm{B}$ 형을 주입한 근육에서 더 높게 관찰 되었다.

결론: 보툴리눔 독소 B형을 주입한 경우 근육 기능의 회복속도는 빠른 반면 근육의 위축은 A 형에 비해 더 오랫동안 지속되었다. 따라서 근육비대의 치료에 있어 보툴리눔 독소 B형이 A형보다 보다 더 효과적이라고 사료된다. (JKDSA 2009; 9: 17 23)

핵심용어: 보툴리눔 독소 $\mathrm{A}$; 보툴리눔 독소 $\mathrm{B}$; 근육비대; 근육위축

\section{INTRODUCTION}

Botulinum toxin type A (BoNT/A), a lethal toxin

Corresponding author: Hyun Jeong Kim, Department of Dental Anesthesiology and Dental Research Institute, School of Dentistry, Seoul National University 28 Yeongeon-dong, Jongno-gu, Seoul 110-768, Korea Tel: +82-2-2072-3042, Fax: +82-2-766-9427

E-mail: dentane@snu.ac.kr produced by Clostridium botulinum, binds to the presynaptic cholinergic nerve terminals and disrupts the release of acetylcholine. It is commonly used for treating various kinds of neuromuscular disorders (Ahnert-Hilger and Bigalke, 1995; Traba Lopez and Esteban, 2001). While common mechanism of botulinum is to disrupt the SNARE (Soluble NSF Attachment Receptor) proteins, Botulinum toxin type A (BoNT/A) and Botulinum toxin type $\mathrm{B}(\mathrm{BoNT} / \mathrm{B})$ have a different 
target sites to disrupt SNARE protein. BoNT/A cleaves SNAP-25 (synapse-associated protein-25) while BoNT/B cleaving VAMP (vesicle-associated membrane protein), called as synaptobrevin, suggesting that clinical effect could be differed in the treatment of BoNT/A compared with BoNT/B. Several lines of clinical studies report that outcome of botulinum treatment varies between serotype. For example, BoNT/B is more effective to treat glabellar rhytidis (Alster TS, 2003), sialorrhea in bulbar onset ALS (Costa et al., 2008). Meanwhile, other reports shows that BoNT/A is better therapeutic choice in the treatment of migrane (Silberstein et al., 2000), spasticity in upper extremeties (Simpson et al., 1996).

Muscle atrophy is associated with early denervation by botulinum toxin (BoNT). This effect is more prominent in hyperactive, dystonic muscle (Jankovic and Orman, 1987; Borodic et al., 1991). In therapeutic setting, BoNT has been injected to treat spastic disease. Recently, the application of BoNT/A has been extended to treat muscle hypertrophy for cosmetic purposes. The injection of BoNT/A was shown be beneficial in treating masseter (Kim et al., 2003) and gastrocnemius muscle hypertrophy (Lee et al., 2004) although the longevity of muscle atrophy appeared to be transient. In contrast, clinical application of BoNT/B have been limited to certain type of disease, given that FDA has only approved the use of BoNT/B for treatment of cervical dystonia. To now, no available studies have been performed to compare therapeutic effect for muscle hypertrophy between BoNT/A and BoNT/B. Whether BoNT/B is effective in the treatment of muscle hypertrophy remains unclear. To pursue our interest, we first examined morphological differences of the anterior tibialis muscle of the rabbit by measuring change of reduction of muscle volume, muscle recovery in experimental study.

\section{MATERIAL AND METHOD}

\section{General design}

All protocols were approved from subcommittee on
Animal Care Research at Seoul National Dental University. Thirty six New Zealand rabbits (weight $2,000-3,000 \mathrm{~g})$ were used for this study. They were randomly allocated into three groups. group 1-9 rabbits with both tibialis muscle injected with a $50 \mu 1$ of normal saline; group 2-9 rabbits with right tibialis muscle injected with a $50 \mu \mathrm{l}$ of BoNT/A 2U (medy-tox corp. Seoul, Korea) and left tibialis muscle injected with a $50 \mu 1$ of BoNT/B 2U (medy-tox corp. Seoul, Korea); group 3-9 rabbits with right tibialis muscle injected with a $50 \mu 1$ of BoNT/A $5 \mathrm{U}$ and left tibialis muscle injected with a $50 \mu \mathrm{l}$ of BoNT/B 5U; group 4-9 rabbits with right tibialis muscle injected with a $50 \mu 1$ of BoNT/A 10U and left tibialis muscle injected with a $50 \mu 1$ of BoNT/B $10 \mathrm{U}$.

\section{Animal preparation}

The rabbit was first anesthetized with an intramuscular injection of an anesthetic cocktail $(1 \mathrm{ml} / \mathrm{kg})$ which consisted of Ketamine (Bayer Animal Health, Suwon, Republic of Korea) and Xylazine (Bayer Animal Health, Suwon, Republic of Korea). The anterior limb was shaved and aseptically prepared with povidone-iodine (Betadine). The skin was excised to expose the tibialis muscle for injection. After removing fascia of tibialis muscle, muscle was fully exposed from origin to insertion point. Before injection, BoNT/A, and BoNT/B was reconstituted with normal saline to reach the concentration of $500 \mathrm{U} / \mathrm{ml}$. BoNT/A, and BoNT/ B was stored at $4^{\circ} \mathrm{C}$ before use after production of mixture. Either toxin or saline was injected into each compartment in the tibialis muscle according to experimental protocols. After injection, muscle injection site was fully squeezed for effective diffusion of BoNT. The injection was performed using a 36-gauge needle attached to a $50 \mu 1$ syringe (Hamilton, Bonaduz, switzeland) throughout experimental period.

\section{Muscle volume measure}

After injecting nomal saline or toxins, the tibialis muscle volume was measured at $1 \mathrm{wk}, 2 \mathrm{wk}$ and 4 
wk after injection at both hindlimbs. The procedure was summarized as briefly. After muscle exposure, the tibialis muscle length was measured by threads and muscle width and thickness was each measured from 5 and 3 points equally divided from origin to insertion by caliper respectively and averaged for calculation of muscle volume at both sides.

The calculations of muscle volume were done by using below equation.

$V=W^{*} L^{*} T$

$\mathrm{V}$ : volume

$\mathrm{W}$ : the mean of the measured width of the 5 points

L: measurement of the muscle length

$\mathrm{T}$ : the mean of the measured muscle thickness of the 3 points

\section{Neuromuscular function monitoring}

We evaluated neuromuscular function by electrical stimulation: single-twitch (single $\mathrm{T}$ ). Neuromuscular function is evaluated by mechanomyography using a peripheral nerve stimulator (NS252; Fisher \& Paykel Health Care, Irvine, CA). The tendon of anterior tibialis muscle was surgically excised and ligated with sutures at each side. The tension of $50 \mathrm{~g}$ was applied to distal end of the muscles. Electrode for electrical stimulation was attatched to the tibial nerves alternatively after both tibial nerves was exposed in posterior part of tibialis muscle. In the single $\mathrm{T}$ mode of stimulation, supramaximal electrical stimuli that was experimentally confirmed by absence of further increase of muscle force with increasing stimuli are applied to a peripheral motor nerve at frequencies ranging from $1.0 \mathrm{~Hz}$. The stimulation-evoked muscle force of the tibialis muscle was recorded. Single twitch value was obtained by measuring height and each response was represented as divided respective value by the normal twitch height. Subsequent recording were conducted according to the same measurement protocols.
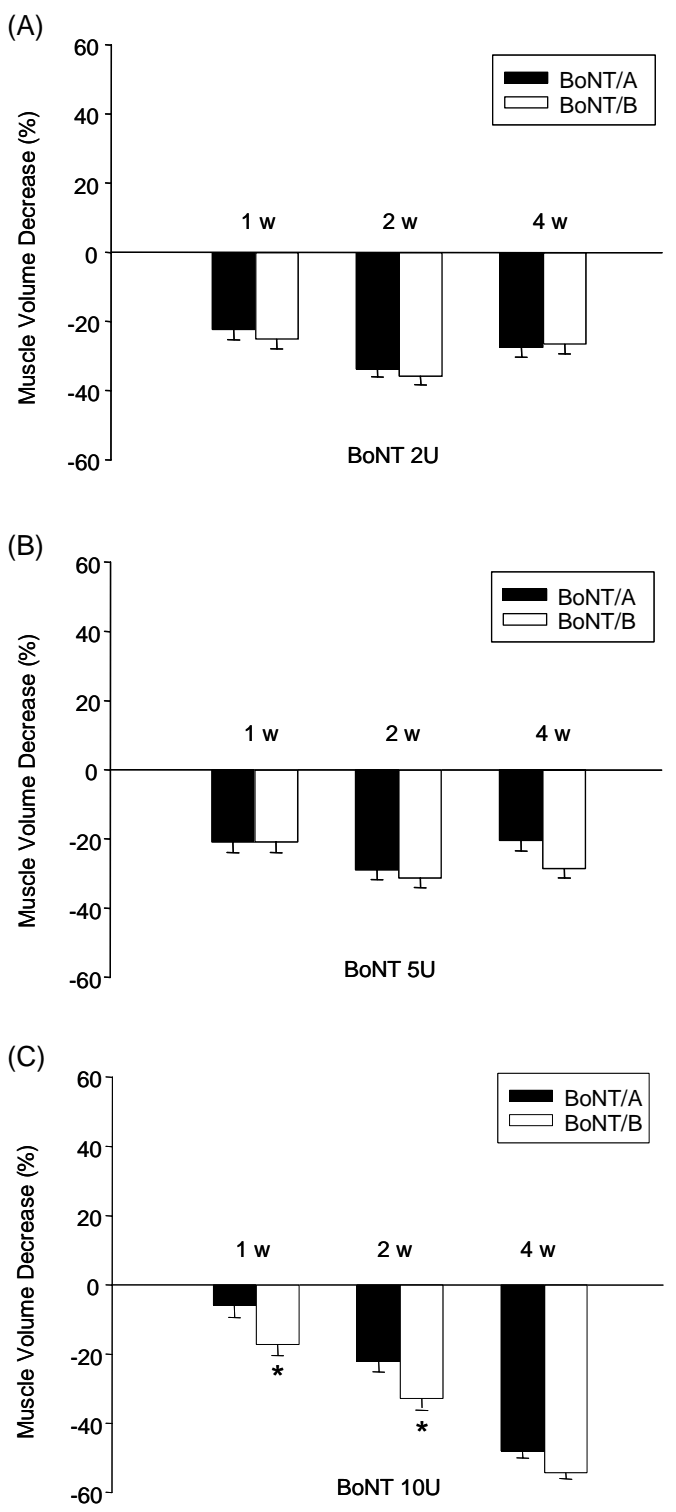

Fig. 1. The decrease of muscle volume after BoNT injection. (A) BoNT 2U (B) BoNT5U (C) BoNT $10 \mathrm{U}$ is injected into the tibialis muscle. The decrease of muscle volume is calculated by the difference between muscle volume in saline injected group and in BoNT injected group dividing muscle volume in saline group. Data represents the mean \pm SEM. * $\mathrm{P}<0.05$ statistically significant from BoNT/A group 
(A)
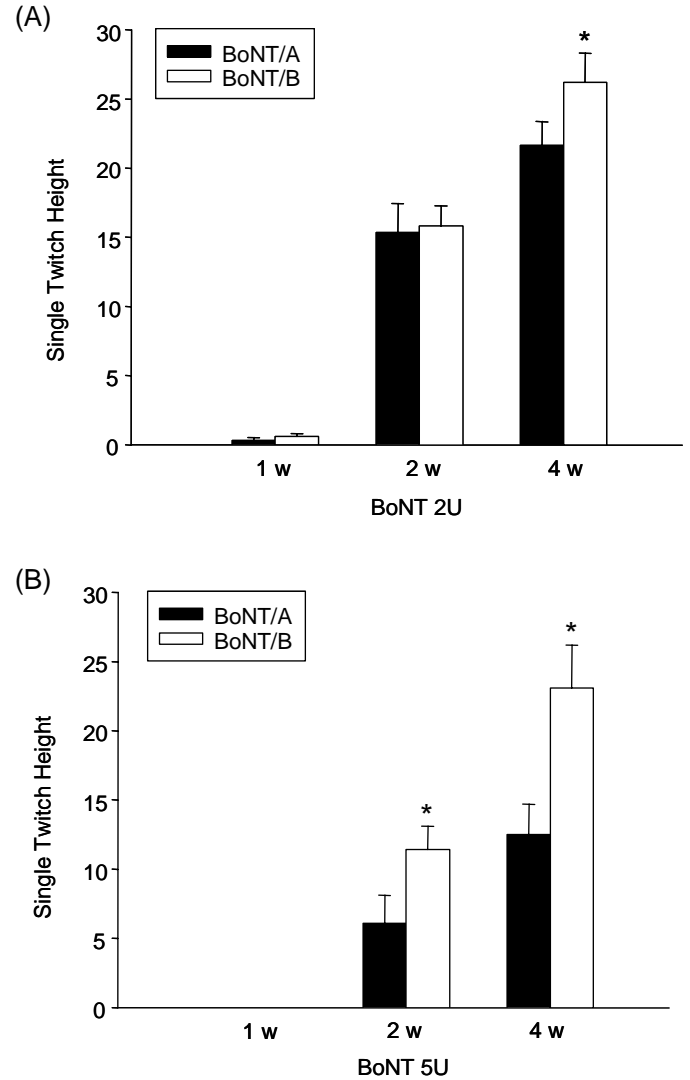

(C)

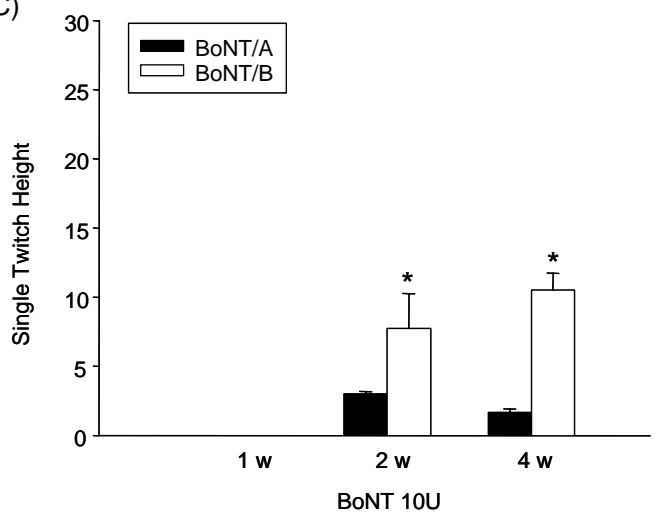

Fig. 2. The change of single twitch height after BoNT injection. Single twithch height is measured at 1,2 and $4 \mathrm{wk}$ after BoNT injection at a dose $2 \mathrm{U}$ (A), $5 \mathrm{U}$ (B), and 10U (C). Data represents the mean \pm SEM. ${ }^{*} \mathrm{P}<0.05$ statistically significant from BoNT/A group

\section{Statistical analysis}

The comparison of muscle sizes and single twitch between BoNT/A and BoNT/B injected muscle were conducted with t-test. A clinical significance was considered to be less than 0.05 of P-value

\section{RESULTS}

The changes of the tibialis muscle volume were shown in Fig 1. BoNT produced decrease of muscle volume loss in dose dependent manner. For BoNT injection at lower dose $(2 \mathrm{U}, 5 \mathrm{U})$, decrease of volume peaked at $2 \mathrm{wk}$ after BoNT injection. For higher dose injection (10U), volume loss was increased throughout experimental period (Fig. 1).

For each administered BoNT dose, we tested the differences of muscle volume loss according to BoNT serotype. As shown in Fig. 1, there was no significant difference in volume loss in the lower dose BoNT injected muscles. Although statistically insignificant, BoNT/B caused a greater loss of volume. Meanwhile, there was a significant difference in the decrease of muscle volume at earlier phase (1,2 wk) after $10 \mathrm{U}$ BoNT injection (-6.0 $\pm 3.0 \%$ (1 wk), $-22.2 \pm 2.9$ $\%$ (2 wk) in BoNT/A group vs $-17.3 \pm 3.0 \%$ (1 wk), $-33.0 \pm 2.5 \%(2 \mathrm{wk})$ in $\mathrm{BoNT} / \mathrm{B}$ group $)$. Overall, the extent of volume reduction was greater in BoNT/B group as compared with BoNT/A (Fig. 1).

As surrogate measure to assess neuromuscular function recovery, the change of single twitch height was recorded and measured in each group after both types of BoNT injection. Regardless of BoNT types and injection dose, the height of single twitch was increase over time. The muscle twitch was not present until $2 \mathrm{wk}$ after BoNT injection at more than $5 \mathrm{U}$ dose (Fig. 2). As shown in Fig. 2, the height of single twitch in BoNT/B was higher than BoNT/A for all groups. Significant difference of single twitch height between type A and B was shown in both BoNT 5U and 10U groups throughout experimental period. 


\section{DISCUSSION}

The present study showed that BoNT causes different neuromuscular effects regarding serotypes especially in regeneration phases. Our study focused on a change in both muscle volume and electromyography between BoNT/A and BoNT/B over time. We showed that muscle atrophy was more prominent despite that recovery of neuromuscular function occurs at early phase in BoNT/B injected muscle.

BoNT is widely used for treatment of muscle hypertrophy. BoNT/A have been reported to be efficacious to treat trapezius hypertrophy (Tan et al., 2007) and masseter hypertrophy (Arikan et al., 2006). Our previous report showed an approximate reduction of $23 \%$ masseter muscle volume that lasted for 12 month in patients treated with BoNT/A (Kim et al., 2003). In agreement with reports, both types of BoN/T injection into the muscle induced fiber atrophy irrespective of the dose. However, muscle volume returned to be increased at $4 \mathrm{wks}$ after BoNT injection at lower dose when reinnervation as evidenced by increased twitch height took place. This suggests that axonal sprouting in nerve-end plate may accelerate muscle regeneration. Terminal axon sprouts occurs at early time after botulinum injection (Pamphlett, 1989). It has been shown that muscle fiber ablated by laser accelerates axonal sprouting during regeneration, thus increasing muscle fiber diameter (Van Mier and Lichtman, 1994). Meanwhile, at higher dose, muscle fiber continued to be atrophied for more than 1 month even though reinnervation occurred. Interestingly, BoNT/B induced a greater amount of volume loss, whereas muscle function restored faster in the treatment of BoNT/B as compared to BoNT/A, which is more prominent at a higher dose. It has been reported that re-innervation in BoNT/B injected muscle arised at earlier stages compared with BoNT/A (Sloop et al., 1997). Contrary to our findings, therapeutic effect of BoNT/B diminishes faster than BoNT/A in treatment of canthal rhytides (Matarasso, 2003) and glabellar rhytides (Neil S. Sadick, 2003; Sadick, 2003) owing to BoNT/B property characterized with rapid offset. The recovery of injected muscle relaxation may contribute to relapse the wrinkles. This may be one of the explanations of therapeutic inefficacy of BoNT/B in treating facial winkles. However, this property of BoNT/B may be advantageous to treat some kind of diseases. For example, such as masseter hypertrophy, mascatory dysfunction after treatment may lead to the disturbance of mastication. If the injected muscle is not strong enough to maintain functional activity, such a treatment may be of less clinical significance. In this sense, BoNT/B may be more effective to treat muscle hypertrophy.

The most reliable method to assess neuromuscular function is stimulate accessible nerve and measure height of single twitch in the innervated muscle (Ali, 1987). In our experiment, the recovery in muscle function was evaluated by applying to electrical stimulation and measuring single twitch height. In previous studies, muscle function was evaluated by measurement of $\mathrm{M}$ wave in BoNT injected muscle. The change of M-wave reflects a disturbance of electrical activity inside denervated muscle. This method is suitable to evaluate BoNT - induced change in muscle function. However, one drawback for this method is inaccurate evaluation of global muscle strength including reinnervated muscle. The electrical signal based on the EMG solely evaluates muscle activity, not restoration of muscle function in the injected muscle. There may be no clinical implication if atrophied muscle by botulinum is not sufficient to recover approximately equal to the strength before injection during recovery phase. In our study, single twitch height, not M-wave, was used as surrogate measure of functional recovery. Single twitch height was measured in the muscle subject to tension, thus reflecting functional recovery more accurately during regeneration. Contrary to M-wave in electromyography, the ratio of single twitch height compared to control approximately reflects the extent to which acetylcholine occupy with its receptor. BoNT prevents the assembly of fusion complex that is essential for 
acetylcholine release, thus blocking muscle contraction. Recovery of neuromuscular function underlies the extent of axonal resprouting given that BoNT irreversibly abrogate the function of neuromuscular synapse in which BoNT is engulfed. In our study, the height of single twitch approximately reached the level before injection in both types of BoNT at 4 weeks of injection. In comparison with BoNT/A, BoNT/B shows better features with regard to resoration of muscle power.

However, our study has some limitation. BoNT/B $\left(\right.$ myobloc $^{(\mathbb{R}}$ ) has recently been approved for treatment of cervical dystonia by Korean Food Drug Association. Our study has been conducted before introduction of BoNT/B into Korea. BoNT/B, used in our study, (courtesy of Medytox Corporation) has been placed under preclinical tests including our study. Although clinical application of our results is somewhat different kind of issues to be further investigated, BoNT/B may be worth being used as alternative to treat muscle hypertrophy from our results.

Taken together, our results may indicate that BoNT/B may be superior in the treatment with patients with muscle hypertrophy and high dose BoNT would be more encouraging to achieve longer duration of effect.

\section{ACKNOWLEDGEMENT}

This work was supported by the Korea Research Foundation Grant funded by the Korean Government (MOEHRD) (KRF-2005-003-E00204). We appreciate Medyrox for the generous supplying BoNT/A and BoNT/B.

\section{REFERENCES}

Ahnert-Hilger G, Bigalke $\mathrm{H}$ : Molecular aspects of tetanus and botulinum neurotoxin poisoning. Prog Neurobiol 1995; 46: 83-96.

Ali $\mathrm{H}$ : Monitoring of neuromuscular function. Journal of Clinical Monitoring and Computing 1987; 4: 185-9. Alster TS Lupton JR: Botulinum toxin type B for dynamic glabellar rhytides refractory to botulinum toxin type A. Dermatol Surg 2003; 29: 516-8.

Arikan OK, Tan FU, Kendi T, Koc C: Use of botulinum toxin type A for the treatment of masseteric muscle hypertrophy. J Otolaryngol 2006; 35: 40-43.

Borodic G, Mills L, Joseph M: Botulinum A toxin for the treatment of adult-onset spasmodic torticollis. Plastic and reconstructive surgery (1963) 1991; 87: 285-9.

Costa J, Rocha ML, Ferreira J, Evangelista T, Coelho M, de Carvalho $\mathrm{M}$ : Botulinum toxin type-B improves sialorrhea and quality of life in bulbaronset amyotrophic lateral sclerosis. J Neurol 2008; 255: 545-50.

Jankovic J, Orman J: Botulinum A toxin for cranialcervical dystonia: a double-blind, placebo-controlled study. Neurology 1987; 37: 616-23.

Kim HJ, Yum KW, Lee SS, Heo MS, Seo K: Effects of botulinum toxin type A on bilateral masseteric hypertrophy evaluated with computed tomographic measurement. Dermatol Surg 2003; 29: 484-9.

Lee H, Lee D, Park Y, Cha M, Kim H, Ha S: Botulinum Toxin A for Aesthetic Contouring of Enlarged Medial Gastrocnemius Muscle. Dermatologic Surgery 2004; 30: $867-71$.

Matarasso S: Comparison of Botulinum Toxin Types A And B: A Bilateral and Double-Blind Randomized Evaluation in the Treatment of Canthal Rhytides. Dermatologic Surgery 2003; 29: 7-13.

Pamphlett R: Early terminal and nodal sprouting of motor axons after botulinum toxin. Journal of the Neurological Sciences 1989; 92: 181-92.

Sadick N: Prospective open-label study of botulinum toxin type B (Myobloc) at doses of 2,400 and 3,000 $\mathrm{U}$ for the treatment of glabellar wrinkles. Dermatologic Surgery 2003; 29: 501-7.

Silberstein S, Mathew N, Saper J, Jenkins S: Botulinum toxin type $\mathrm{A}$ as a migraine preventive treatment. Headache 2000; 40: 445-50.

Simpson D, Alexander D, O'brien C, Tagliati M, Aswad $\mathrm{A}$, Leon $\mathrm{J}$, et al: Botulinum toxin type $\mathrm{A}$ in the treatment of upper extremity spasticity: a randomized, double-blind, placebo-controlled trial. Neurology 1996; 46: 1306-10.

Sloop RR, Cole BA, Escutin RO: Human response to botulinum toxin injection: type B compared with type A. Neurology 1997; 49: 189-94.

Tan EK, Lo YL, Thomas J, Chan LL: Bilateral trapezius hypertrophy with dystonia and atrophy. CMAJ 2007; 
176: $1702-3$.

Traba Lopez A, Esteban A: Botulinum toxin in motor disorders: practical considerations with emphasis on interventional neurophysiology. Neurophysiol Clin 2001; 31: 220-9.
Van Mier P, Lichtman J: Regenerating muscle fibers induce directional sprouting from nearby nerve terminals: studies in living mice. Journal of Neuroscience $1994 ; 14$ : 5672-86. 